\title{
A Study on the Use and Risk of Artificial Intelligence in the Appraisal Industry
}

\author{
HyunRim Ko, Appraiser, Dept. of Appraisal, Samil Appraisal Co.Ltd., \#606, 205 dong, 111, Songpa-daero, \\ Songpa-gu, Seoul, Korea, 05837, Korea, appraiser11@naver.com \\ *JongChil Shin, Professor, Dept. of Real Estate Studies, Konkuk University, \#605, Haebongkwan, 120, \\ Neungdong-ro, Gwangjin-gu, Seoul, Korea, 05029, Korea, sjc4504@gmail.com \\ *Corresponding Author
}

\begin{abstract}
The purpose of this study is to investigate Korean appraisers' perception of the potential for the utilization of Artificial Intelligence (AI) and the related risks of using AI in the appraisal industry. We conducted a mobile survey for appraisers from February 10 to 18, 2020. We collected survey data from 193 respondents. Frequency Analysis and Multiple Response Analysis were performed for basic analysis. Factor Analysis was used to analyze various types of risks in using AI for appraisal industry. To visualize these risks, we drew positioning maps using the Multidimensional Scaling Method. Appraisers have a positive perception on the introduction of AI in the appraisal industry, but they also recognized the negative effects related to job losses and job replacements. They mainly considered collateral, consulting, and taxation appraisal as areas with high potential for using AI and areas with high replaceability of human labor. They were more aware of the substitution risk by AI in these areas. They were highly aware of accountability, privacy \& security, and technical error risks. However, fairness, transparency, and reliability risks are generally perceived as low risk issues. While prior studies have mainly studied the analysis method of applying AI to the mass appraisal model, this study focused on the use and risk of AI. Understanding the perception of industry experts on the utilization of AI helps to minimize the potential risks that may arise when $\mathrm{AI}$ is introduced on a large scale.
\end{abstract}

Keywords: Appraisal Industry, Risks of using Artificial Intelligence (AI), Multidimensional Scaling Method (MDS), MDPREP (Multidimensional Preference), Positioning Map

Received: 05.12.2020 $\quad$ Accepted: 12.01.2021 $\quad$ Published: 06.02.2021

\section{INTRODUCTION}

Artificial Intelligence (AI) is a technology that can perform many tasks usually done by humans. It enables computers to handle tasks such as natural language processing and facial recognition. The classification of AI can be divided into various categories. American philosopher John Searle classifies AI as Weak AI and Strong AI depending on the level of intelligence [1]. While Strong AI is artificial intelligence can handle any task or problem in any domain like human being, Weak AI is artificial intelligence that implements on a specific task domain. In recent years, as AI technology has developed, better solutions utilizing combinations of Weak AIs are appearing. It is difficult to explain the recently developed AI technology only through the dichotomous classification of AI. Accordingly, an intermediate concept called Hybrid AI has emerged as a solution in which several Weak AIs are combined. Unlike in the past, AI is developing at a faster pace than Weak AI $[1,2]$. However, the use of AI is usually considered a double-edged sword. This is because the use of AI comes with both advantages and risks. Since the use of AI can be both an opportunity and a threat, we need to recognize the risks of using AI technology and develop appropriate control and management capabilities for it. This study aims to analyze how Korean appraisers think about using $\mathrm{AI}$ and how they perceive the risks before AI technology is fully introduced into the appraisal industry.

\section{Related studies}

There are three main advantages that humans can obtain when using AI. First, humans can overcome unfavorable physical limitations by using AI. AI can be used in various fields such as drug development, medical treatment, and smart factories. Since AI can collect information and analyze it more quickly than humans, it could help solve human problems such as disease, poverty, and war in the long run. Second, by using AI, humans can work more efficiently and improve their quality of life. When AI replaces mundane human labor, humans can concentrate their free time on creative activities. The use of AI is still in its early 
stages, but AI can achieve widespread development beyond human intelligence can achieve, and can improve production capacity [3]. Third, humans can make complex decisions quickly by using AI. Data analysis and modeling using AI present the results in consideration of the number of cases available for analysis. This can increase the efficiency of decision making and enhance economic added value.

Despite these advantages, AI can pose serious risks to humans. Cheatham et al. (2019) pointed out data difficulties, technology troubles, security snags, misbehaving models, and interaction issues as risks that AI presents [3]. Băjenescu (2018) said that when using Artificial Intelligence, there could be algorithm bias, overestimation of the capabilities of AI, programmatic errors, risk of cyber-attacks, legal risks and liabilities, and reputational risks [2]. In addition, he argued that Artificial Intelligence carries both risks and opportunities on a global scale, such as misuse risks, accident risks, safety and reliability risks, and the potential for widespread cybercrime [2]. Thus, the risks of AI technology present important problems throughout society and the economy. It is necessary to review and manage the risks of AI before AI technology reaches the level of Strong AI.

To this end, research and efforts on AI ethics and AI governance are being conducted worldwide. The risks of AI can be reviewed through the principles of AI governance. Microsoft proposes fairness, inclusiveness, reliability and safety, transparency, privacy and security, and accountability as the principles of AI governance [4]. Google asserts use of AI should be socially beneficial, be built and tested for safety, be accountable to people, avoid creating or reinforcing unfair bias, incorporate privacy design principles, and uphold high standards of scientific excellence [5]. USACM(Association for Computing Machinery US Public Policy Council) suggests awareness, access and redress, accountability, explanation, data provenance, auditability, and validation \& Testing [6].

Several common AI risks have been found in previous studies. First, when using AI, there may be a risk related to fairness. If AI operates with ingrained biases, it may not maintain objectivity or promote diversity, resulting in unfair results. Second, when using AI, there may be a reliability risk. AI systems must be operated safely and stably. If the integrity of data accumulation or the security of the data is not guaranteed, the accuracy of the algorithm may be compromised. Third, when using AI, there may also be a transparency risk. Since the algorithm of AI is a black box, it may be difficult to explain the results of processing the algorithm. Because the AI structure has a complex structure based on a nonlinear algorithm, it is difficult to specifically grasp which input data contributed to the result and to prove the causal relationship. Fourth, when using AI, there may be an accountability risk. Decisions made by AI algorithms are made by machines, but they are not accountable for the harm they do. The Al's user bears those consequences. Fifth, when using AI, there may be privacy \& security risks. AI systems collect and analyze data using an algorithm for machine learning based on huge amounts of data. Currently, the accuracy of AI can only be improved by collecting large amounts of high-quality data. To acquire this data, companies may infringe on the privacy of consumers. In addition, if security precautions are not sufficient, personal information may be exposed. [3]. Sixth, the use of AI can lead to technical errors. AI can cause technical errors at various stages, including programming errors, interaction errors between developers and AI, and errors in the data itself. If technical errors occur, an AI may not work properly, leading to unexpected risks.

In order to look at research related to AI technology in the appraisal industry, it is necessary to review the literature since the early 1980s when the computerization of real estate appraisal began. Initially, it was approached in a way that automated the typical behavior of valuers or to develop prototypes [7]. Rossini et al. (1992) proposed an automatic evaluation system for mass evaluation [8]. Detweiler and Radigan (1996) also described an automatic evaluation system (CAREAS, Computer Assisted Real Estate Appraisal System) developed for commercial purposes such as mortgage loans [9]. Recently, AI-based methods such as artificial neural network analysis have been introduced in mass appraisal studies [10-13]. However, artificial neural networks have a black box characteristic, lack consistency, and display difficulty with repetitive results. Some studies [10,14] have shown that the evaluations based on artificial neural network analysis have improved, while others have shown no improvement in evaluations based on artificial neural networks [12]. In addition, in some studies, the artificial neural network technique did not improve the evaluation compared to traditional multiple regression analysis (MRA) [11,13]. Furthermore, by using Both MRA and AI-based analysis methods, various results are presented by simulating each scenario [15].

As such, previous studies related to $\mathrm{AI}$ in the appraisal industry have focused on analysis techniques to obtain better results in estimating the value of mass appraisal models. As mentioned earlier, while there are manifold advantages of using AI, unexpected risks can always emerge. Therefore, to control and 
manage the risks of AI for the industries where it is used, it is necessary to proactively identify how members of each industry are aware of the risks. Through these efforts, AI can be properly utilized and its risks can be minimized.

\section{Data and methods}

\section{Data}

The purpose of this study is to investigate appraisal experts' perceptions on the use and risks of Artificial Intelligence when it is introduced into the appraisal industry. To this end, a mobile survey was conducted from February 10 to February 18, 2020 for appraisers in Korea. The questionnaire used a 7-point Likert scale to examine appraisers' perception of use and risks of AI. A total of 214 respondents were surveyed, of which 193 results were used for the analysis and 21 were disqualified.

\section{Method}

Artificial Intelligence could have a significant impact on the real estate industry, market, and employment. In this research, we aim to investigate the appraiser's perception of the use and risk of using AI in the appraisal industry.

First of all, we investigated the appraiser's perception of the effects that can be displayed when introducing AI. Then, we investigated the appraiser's perception on the changes of the industry by AI. These were analyzed using Frequency Analysis and Multiple Response Analysis.

Next, we analyzed the appraisers' perceptions of the risks of using AI. Using Factor Analysis and Reliability Analysis, we identified various types of risks related to using AI and verified the validity and reliability of the measurement tool. In addition, the positioning map was drawn using the Multidimensional Scaling Method (MDS) for the appraisers' perception of the risks of using AI. We used MDPREP (Multidimensional Preference) provided by MDSX to derive the positioning map.

\section{Variables and scales}

The risk related to using AI is a multidimensional concept. Therefore, it is necessary to define its dimensions to be measurable and to construct scales. In order to examine the appraisers' perception of the risks that may arise when AI technology replaces an appraisal task, we must identify potential risks. This study defines risks based on common risks that may occur when using AI drawn from previous studies. As shown in [Table 1], the risks related to using AI consist of six dimensions including fairness, reliability, transparency, accountability, privacy \& security, and technical error risks. In this study, the scales related to each type of risk are constructed using a 7-point Likert scale.

\section{Table 1: Definition and Measurement Scales of Risks}

\begin{tabular}{|l|l|l|}
\hline Risk & Definition & Measurement scales \\
\hline \multirow{4}{*}{$\begin{array}{l}\text { Fairness } \\
\text { risk }\end{array}$} & $\begin{array}{l}\text { The risk that hinders } \\
\text { objectivity, diversity, and } \\
\text { equality of information when } \\
\text { the AI system performs the } \\
\text { appraisal work }\end{array}$ & $\begin{array}{l}\text { (a) I don't think that if Al system performs appraisal } \\
\text { work, it won't be fair. }\end{array}$ \\
\hline (b) I think AI system is more likely to lack objectivity if \\
it performs appraisal work.
\end{tabular}




\begin{tabular}{|l|l|l|}
\hline & & $\begin{array}{l}\text { (i) I think if AI system performs appraisal work, there } \\
\text { may be a conflict of social responsibility for the results } \\
\text { of appraisal. }\end{array}$ \\
\hline Privacy \& \\
security risk & $\begin{array}{l}\text { The risk of weak privacy and } \\
\text { security when the AI system } \\
\text { performs appraisal work }\end{array}$ & $\begin{array}{l}\text { (j) I think that if AI system performs appraisal work, } \\
\text { privacy will be vulnerable. }\end{array}$ \\
\cline { 3 - 3 } $\begin{array}{l}\text { Technical } \\
\text { errors }\end{array}$ & $\begin{array}{l}\text { The risk of think that cybercrime is more likely to occur if AI } \\
\text { system performs an appraisal work. }\end{array}$ \\
\hline $\begin{array}{l}\text { when AI system performs } \\
\text { appraisal work }\end{array}$ & $\begin{array}{l}\text { (l) I think that if AI system performs appraisal work, } \\
\text { there is a high possibility of algorithm malfunction. }\end{array}$ \\
\cline { 3 - 3 } & $\begin{array}{l}\text { (m) I think that if AI system performs appraisal work, } \\
\text { there is a high possibility of technical system errors. }\end{array}$ \\
\hline
\end{tabular}

\section{Result and discussion}

\section{Analysis of perception on the use of AI technology}

First, we investigate the general perception of the utilization of AI technology in the appraisal industry. [Table 2] presents the result of appraisers' perception when AI technology is utilized in the industry.

As shown in [Table 2], the means of responses range from 4.59 to 4.87 . This shows that appraisers tend to positively perceive the use of AI. In particular, appraisers think that the use of AI is likely to improve the appraisal process. In addition to this positive perception of the use of AI, appraisers display concern that service fees for appraisal services could be reduced.

Second, we question appraisers about the impact on employment and the real estate market if AI is introduced in the industry. In general, appraisers think that $\mathrm{AI}$ is likely to replace the work of appraisers and that employment of appraisers will decrease as the use of AI increases. As shown in [Table 3], the response mean for the job losses item is high at 4.85, indicating that appraisers are concerned about job losses. Also, appraisers think that if appraisal services using AI become more prevalent, information asymmetry in the real estate market will decrease and the market efficiency will be improved.

Third, in [Table 4], we analyze the appraisal areas where AI is likely to be utilized as a replacement for human tasks. Appraisers think that consulting, collateral appraisal, and taxation appraisal are areas where AI is likely to be used. In addition, they think collateral appraisal, consulting, and taxation appraisal are appraisal areas that could be replaced by AI. These result shows there is a high possibility that AI will substitute for appraisers in the areas with high potential for AI use.

Fourth, we ask about appraisal implementation stages that AI is most likely to be utilized and replace appraisers. Appraisers respond that 'data collection and organization' and 'data review and value formation factor analysis' as the appraisal implementation stages where AI is likely to be utilized. Appraisers think 'data review and value formation factor analysis' and 'data collection \& organization' are the appraisal implementation stages where $\mathrm{AI}$ is most likely to replace appraisers. These responses are shown in [Table 5]. These results show there is a high possibility that AI will substitute for appraisers in the appraisal implementation stages with high potential of using AI.

Table 2: The impact on the appraisal industry $(n=193)$

\begin{tabular}{|l|l|l|l|}
\hline Contents & Scales (1 = strongly disagree, 7 = strongly agree) & Mean & S.E \\
\hline $\begin{array}{l}\text { (1) Increase the speed of } \\
\text { work }\end{array}$ & $\begin{array}{l}\text { Using AI, it is possible to perform appraisal work more } \\
\text { quickly. }\end{array}$ & 4.74 & 1.23 \\
\hline (2) Increase efficiency & $\begin{array}{l}\text { Using AI, it is possible to perform appraisal work more } \\
\text { efficiently. }\end{array}$ & 4.81 & 1.18 \\
\hline (3) Increase expertise & $\begin{array}{l}\text { Using AI, appraisers will be able to concentrate on their } \\
\text { professional work area. }\end{array}$ & 4.61 & 1.28 \\
\hline $\begin{array}{l}\text { (4) Diversify appraisal } \\
\text { service }\end{array}$ & $\begin{array}{l}\text { Using AI, appraisers will be able to provide more diverse } \\
\text { appraisal services. }\end{array}$ & 4.80 & 1.24 \\
\hline $\begin{array}{l}\text { (5) Improve error of } \\
\text { appraisal price }\end{array}$ & $\begin{array}{l}\text { Using AI, appraisers will be able to improve the error in } \\
\text { appraisal price. }\end{array}$ & 4.70 & 1.30 \\
\hline $\begin{array}{l}\text { (6) Improve appraisal } \\
\text { process }\end{array}$ & $\begin{array}{l}\text { Using AI, appraisers will be able to improve appraisal } \\
\text { process. }\end{array}$ & $\mathbf{4 . 8 7}$ & 1.18 \\
\hline $\begin{array}{l}\text { (7) Reduce the cost of work } \\
\text { execution }\end{array}$ & $\begin{array}{l}\text { Using AI, it is possible to reduce the costs required to } \\
\text { perform appraisal work. }\end{array}$ & $\mathbf{4 . 5 9}$ & 1.31 \\
\hline (8) Reduce the payment for & Using AI, it is possible to reduce the payment price of & 4.70 & 1.45 \\
\hline
\end{tabular}


Table 3: The Impact on Employment and Real Estate Market $(n=193)$

\begin{tabular}{|l|l|c|c|}
\hline Contents & Scales (1 = strongly disagree, 7 = strongly agree) & Mean & S.E \\
\hline $\begin{array}{l}\text { (1) The possibility to replace } \\
\text { appraisal by AI }\end{array}$ & $\begin{array}{l}\text { If AI develops, AI is likely to replace the work area of } \\
\text { appraisers. }\end{array}$ & 4.46 & 1.40 \\
\hline $\begin{array}{l}\text { (2) The job losses in } \\
\text { appraisal industry }\end{array}$ & $\begin{array}{l}\text { If appraisal services utilizing AI increase, employment of } \\
\text { appraisers will decrease. }\end{array}$ & $\mathbf{4 . 8 5}$ & 1.39 \\
\hline $\begin{array}{l}\text { (3) The reduction of } \\
\text { information asymmetry in } \\
\text { the real estate market }\end{array}$ & $\begin{array}{l}\text { If appraisal service using AI increases, the asymmetry of } \\
\text { information in the real estate market will decrease. }\end{array}$ & 4.54 & 1.42 \\
\hline $\begin{array}{l}\text { (4) efficiency } \\
\text { improvement in the } \\
\text { real estate market }\end{array}$ & $\begin{array}{l}\text { If appraisal service using AI increases, the efficiency of } \\
\text { the real estate transaction market will be improved. }\end{array}$ & 4.50 & 1.30 \\
\hline
\end{tabular}

Table 4: The Potential of using AI for Appraisal Areas (Multiple Response)

\begin{tabular}{|c|c|c|c|c|c|c|c|}
\hline \multicolumn{4}{|c|}{ Appraisal areas where AI is likely to be used } & \multicolumn{4}{|c|}{ Appraisal areas that are likely to be replaced } \\
\hline Appraisal areas & $\mathrm{N}$ & $\%$ & $\begin{array}{l}\% \text { of } \\
\text { cases }\end{array}$ & Appraisal areas & $\mathrm{N}$ & $\%$ & $\begin{array}{ll}\% & \text { of } \\
\text { cases } & \end{array}$ \\
\hline $\begin{array}{l}\text { Auction } \\
\text { Litigation }\end{array}$ & 56 & $12.3 \%$ & $29.0 \%$ & $\begin{array}{l}\text { Auction } \\
\text { Litigation }\end{array}$ & 42 & $10.2 \%$ & $21.8 \%$ \\
\hline Collateral & 90 & $19.7 \%$ & $46.6 \%$ & Collateral & 98 & $23.8 \%$ & $50.8 \%$ \\
\hline Consulting & 129 & $28.3 \%$ & $66.8 \%$ & Consulting & 92 & $22.4 \%$ & $47.7 \%$ \\
\hline $\begin{array}{l}\text { General } \\
\text { Transaction }\end{array}$ & 52 & $11.4 \%$ & $26.9 \%$ & $\begin{array}{l}\text { General } \\
\text { Transaction }\end{array}$ & 58 & $14.1 \%$ & $30.1 \%$ \\
\hline Compensation & 49 & $10.7 \%$ & $25.4 \%$ & Compensation & 33 & $8.0 \%$ & $17.1 \%$ \\
\hline Taxation & 80 & $17.5 \%$ & $41.5 \%$ & Taxation & 88 & $21.4 \%$ & $45.6 \%$ \\
\hline Total & 456 & $100.0 \%$ & $236.3 \%$ & Total & 411 & $100.0 \%$ & $213.0 \%$ \\
\hline
\end{tabular}

Table 5: The Potential of using AI for Appraisal Implementation Stages (Multiple Response)

\begin{tabular}{|c|c|c|c|c|c|c|c|}
\hline \multicolumn{4}{|c|}{ Stages where AI is likely to be used } & \multicolumn{4}{|c|}{ Stages that are likely to be replaced by AI } \\
\hline $\begin{array}{l}\text { Appraisal } \\
\text { implementation stages }\end{array}$ & $\mathrm{N}$ & $\%$ & $\begin{array}{l}\% \text { of } \\
\text { cases }\end{array}$ & $\begin{array}{l}\text { Appraisal } \\
\text { implementation } \\
\text { stages }\end{array}$ & $\mathrm{N}$ & $\%$ & $\begin{array}{l}\% \text { of } \\
\text { cases }\end{array}$ \\
\hline $\begin{array}{l}\text { Confirmation of basic } \\
\text { factors }\end{array}$ & 49 & $10.0 \%$ & $25.4 \%$ & $\begin{array}{l}\text { Confirmation of basic } \\
\text { factors }\end{array}$ & 49 & $10.5 \%$ & $25.4 \%$ \\
\hline $\begin{array}{l}\text { Establishment of the } \\
\text { plan }\end{array}$ & 52 & $10.6 \%$ & $26.9 \%$ & $\begin{array}{l}\text { Establishment of the } \\
\text { plan }\end{array}$ & 45 & $9.6 \%$ & $23.3 \%$ \\
\hline $\begin{array}{l}\text { Inspection of subject } \\
\text { property }\end{array}$ & 50 & $10.2 \%$ & $25.9 \%$ & $\begin{array}{l}\text { Inspection of subject } \\
\text { property }\end{array}$ & 39 & $8.4 \%$ & $20.2 \%$ \\
\hline $\begin{array}{l}\text { Data collection \& } \\
\text { organization }\end{array}$ & 135 & $27.5 \%$ & $69.9 \%$ & $\begin{array}{l}\text { Data collection \& } \\
\text { organization }\end{array}$ & 122 & $26.1 \%$ & $63.2 \%$ \\
\hline $\begin{array}{l}\text { Data review and } \\
\text { value } \\
\text { factor analysis }\end{array}$ & 132 & $26.9 \%$ & $68.4 \%$ & $\begin{array}{l}\text { Data review and } \\
\text { value formation } \\
\text { factor analysis }\end{array}$ & 128 & $27.4 \%$ & $66.3 \%$ \\
\hline $\begin{array}{lr}\text { Appraisal } & \text { approach } \\
\text { selection } & \text { and } \\
\text { application } & \\
\end{array}$ & 37 & $7.5 \%$ & $19.2 \%$ & $\begin{array}{lr}\text { Appraisal } & \text { approach } \\
\text { selection } & \text { and } \\
\text { application } & \\
\end{array}$ & 46 & $9.9 \%$ & $23.8 \%$ \\
\hline $\begin{array}{lr}\text { Decision } & \text { and } \\
\text { announcement } & \text { of } \\
\text { appraised value } & \end{array}$ & 36 & $7.3 \%$ & $18.7 \%$ & $\begin{array}{lr}\text { Decision } & \text { and } \\
\text { announcement } & \text { of } \\
\text { appraised value } & \end{array}$ & 38 & $8.1 \%$ & $19.7 \%$ \\
\hline Total & 491 & $100.0 \%$ & $254.4 \%$ & Total & 467 & $100.0 \%$ & $242.0 \%$ \\
\hline
\end{tabular}

\section{Analysis of perception on the risks in using AI technology}

In this study, we attempt to analyze the appraisers' perceptions on risks that may arise from the use of AI in the appraisal industry. We measure appraisers' perceptions on the risks by using the measurement 
scales summarized in [Table 1]. [Table 6] shows the means of each measurement item related to risks. As shown in [Table 6], means for measurement items related to an accountability risk are the highest, and the means related to a fairness risk are the lowest. Because accountability risk is directly related to economic, social, and legal conflicts, appraisers consider an accountability risk as important risk of using AI. On the other hand, because fairness risk is difficult to grasp before experiencing it firsthand using AI, appraisers evaluate fairness risk as less important.

[Table 6] shows the results of the Factor Analysis and Reliability Analysis. We use Factor Analysis to analyze various types of risks of using AI. The Principal Component Analysis method was used as the factor extraction method, and the Varimax method was used for factor rotation. The result of Factor Analysis shows that KMO (Kaiser-Meyer-Olkin) is 0.884, and Bartlett's spherical test shows a significant probability of $0.000(\mathrm{p}<0.01)$, indicating the Factor Analysis model is suitable. Commonality is more than 0.6 , the percentage of cumulative variance explained is $92.21 \%$. The result of Factor Analysis shows that the six types of risk factors have convergent validity and discriminant validity. The result of Reliability Analysis shows that the Cronbach's alphas of measurement items are all above 0.8. The result of Reliability Analysis shows measurement items are reliable.

Table 6: The Result of Factor Analysis and Reliability Analysis

\begin{tabular}{|c|c|c|c|c|c|c|c|c|c|c|}
\hline \multirow{2}{*}{\multicolumn{2}{|c|}{$\begin{array}{l}\text { Types of risk } \\
\text { in using AI }\end{array}$}} & \multirow{2}{*}{$\begin{array}{l}\text { Cronba } \\
\text { ch' } \\
\text { alpha }\end{array}$} & \multicolumn{6}{|c|}{ Component } & \multirow{2}{*}{ Mean } & \multirow{2}{*}{ S.E } \\
\hline & & & 1 & 2 & 3 & 4 & 5 & 6 & & \\
\hline \multirow{3}{*}{$\begin{array}{l}\text { Accountab } \\
\text { ility }\end{array}$} & (g) & \multirow{3}{*}{0.97} & 0.86 & 0.09 & 0.28 & 0.24 & 0.16 & 0.20 & 5.05 & 1.39 \\
\hline & (h) & & 0.85 & 0.15 & 0.27 & 0.28 & 0.14 & 0.19 & 4.99 & 1.36 \\
\hline & (i) & & 0.85 & 0.21 & 0.22 & 0.25 & 0.20 & 0.16 & 5.04 & 1.35 \\
\hline \multirow{2}{*}{ Fairness } & (a) & \multirow{2}{*}{0.87} & 0.21 & 0.82 & 0.16 & 0.14 & 0.23 & 0.25 & 3.91 & 1.45 \\
\hline & (b) & & 0.09 & 0.88 & 0.12 & 0.14 & 0.27 & 0.10 & 3.74 & 1.43 \\
\hline \multirow{2}{*}{$\begin{array}{l}\text { Privacy \& } \\
\text { security }\end{array}$} & (j) & \multirow{2}{*}{0.93} & 0.25 & 0.15 & 0.88 & 0.13 & 0.21 & 0.08 & 4.40 & 1.40 \\
\hline & $(\mathrm{k})$ & & 0.30 & 0.14 & 0.88 & 0.17 & 0.09 & 0.15 & 4.40 & 1.39 \\
\hline \multirow{2}{*}{$\begin{array}{l}\text { Technical } \\
\text { errors }\end{array}$} & (l) & \multirow{2}{*}{0.93} & 0.48 & 0.20 & 0.16 & 0.76 & 0.21 & 0.14 & 4.68 & 1.30 \\
\hline & $(\mathrm{m})$ & & 0.33 & 0.18 & 0.22 & 0.81 & 0.17 & 0.26 & 4.61 & 1.34 \\
\hline \multirow{2}{*}{$\begin{array}{l}\text { Transpare } \\
\text { ncy }\end{array}$} & (e) & \multirow{2}{*}{0.89} & 0.27 & 0.35 & 0.18 & 0.19 & 0.74 & 0.28 & 4.26 & 1.39 \\
\hline & (f) & & 0.18 & 0.37 & 0.20 & 0.18 & 0.78 & 0.21 & 4.17 & 1.51 \\
\hline \multirow{2}{*}{ Reliability } & (c) & \multirow{2}{*}{0.86} & 0.27 & 0.48 & 0.21 & 0.18 & 0.25 & 0.67 & 4.44 & 1.44 \\
\hline & (d) & & 0.32 & 0.20 & 0.13 & 0.32 & 0.34 & 0.73 & 4.65 & 1.37 \\
\hline \multicolumn{3}{|l|}{ Eigen Value } & 3.00 & 2.18 & 2.01 & 1.72 & 1.69 & 1.40 & & \\
\hline \multicolumn{3}{|c|}{$\%$ of Variance } & 23.09 & 16.73 & 15.44 & 13.23 & 12.97 & 10.75 & & \\
\hline \multicolumn{3}{|c|}{ Cumulative \% } & 23.09 & 39.82 & 55.26 & 68.50 & 81.46 & 92.21 & & \\
\hline \multicolumn{9}{|c|}{ Rotation : Varimax, $\mathrm{KMO}=0.884$} & & \\
\hline
\end{tabular}

Finally, we conduct Multidimensional Scaling Analysis to better understand the relationships between various types of risks and appraisal areas or appraisal implementation stages using AI technology. In order to draw a positioning map, we use the means of the factor scores related to each type of risk according to appraisal areas. [Figure 1] is a perception map showing the relationship between risks and appraisal areas using AI. 


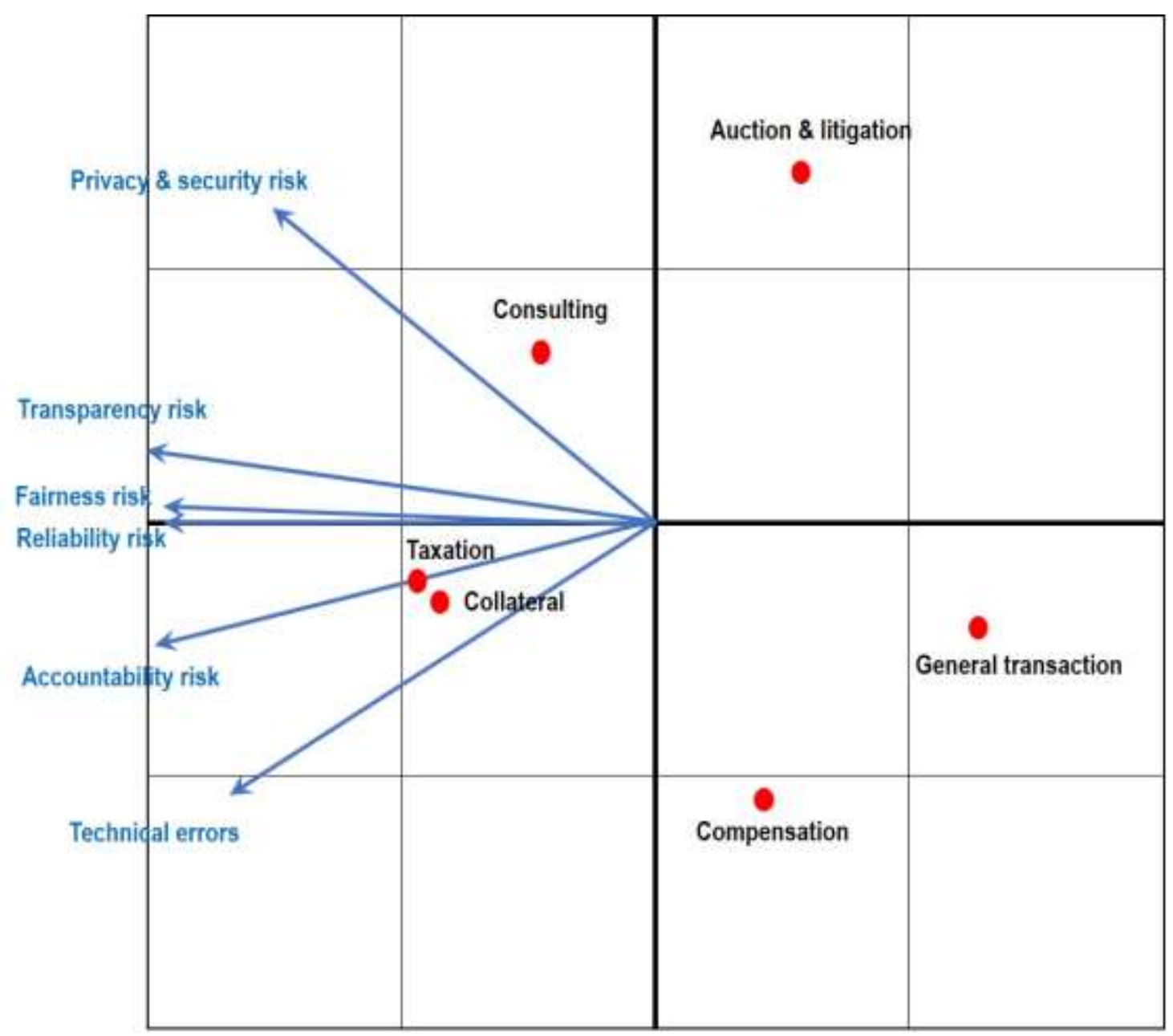

Figure 1. Positioning Map between Risks and Appraisal Areas

According to [Figure 1], appraisers who want to use AI technology in collateral appraisal and taxation appraisal are more concerned about various risks such as accountability, reliability, fairness, and technical errors. On the other hand, appraisers who want to use AI technology in consulting and auction \& litigation appraisal are more worried about privacy and security risks.

Next, a positioning map is drawn to show the relationship between risks and appraisal implementation stages. We use the means of factor scores related to each type of risk according to appraisal implementation stages to draw a positioning map. [Figure 2] shows the relationship between risks and appraisal implementation stages using AI. 


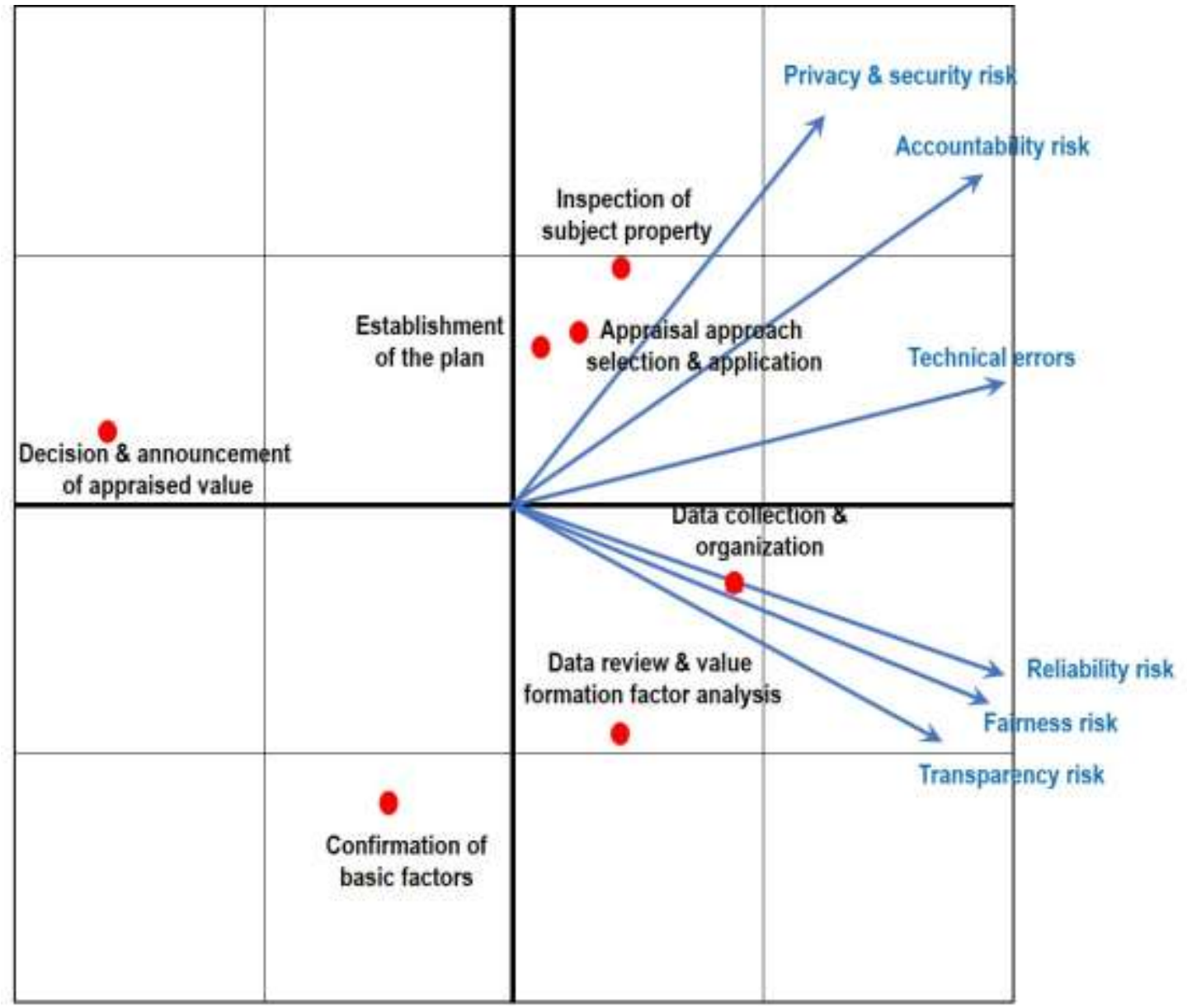

Figure 2. Positioning Map between Risks and Appraisal Implementation stages

According to [Figure 2], appraisers who want to use AI technology in the stages of 'inspection of subject property,' 'appraisal approach selection and application,' 'establishment of the plan' are more concerned about accountability, privacy \& security, and technical error risks. On the other hand, appraisers who want to use AI technology in the stages of 'data collection \& organization' and 'data review and value formation factor analysis' are worried about fairness, reliability, and transparency risks.

What is unusual here is that the stage of 'decision \& announcement of appraised value' shows a relatively low relationship with various risks in using AI technology. The 'decision \& announcement of appraised value' stage is the final stage where appraisers make professional value judgments. It shows that appraisers believe that $\mathrm{AI}$ is unlikely to replace professional judgment.

\section{Conclusion}

This study investigates how appraisers perceive the use and risks of using AI in the appraisal industry. Based on the survey data, this study shows appraisers' perception on using AI technology.

This study shows that appraisers generally have positive perceptions on the use of AI in the appraisal industry. They believe that AI technology will make appraisal work more efficiently. They think that information asymmetry in the real estate market will be alleviated and market efficiency will be improved. However, they are also aware of potential side effects such as job losses and replacement of human labor with AI. Appraisers perceive that AI technology is likely to substitute for appraisers in areas such as collateral appraisal, consulting, and taxation appraisal. In addition, appraisers respond that AI technology is likely to substitute for appraisers in the appraisal implementation stages such as 'data collection \& organization' and 'data review \& value formation factor analysis.'

Regarding the risks of using AI technology, appraisers perceive the risks related to accountability, technical error, privacy \& security as the most important. On the other hand, they perceive the lowest fairness risk. According to the MDS Analysis, appraisers who try to use AI technology in collateral appraisal and taxation appraisal are more concerned about accountability, reliability, fairness, and 
technical error risks. Appraisers seeking to use AI technology in consulting and auction \& litigation appraisal are more worried about privacy and security risks. Regarding appraisal implementation stages, appraisers wanting to use AI technology in the stages of 'inspection of subject property,' 'appraisal approach selection and application,' and 'establishment of the plan' are more concerned about accountability, privacy \& security, and technical error risks. Appraisers planning to use AI technology in the stages of 'data collection \& organization' and 'data review and value formation factor analysis' are worried about fairness, reliability, and transparency risks.

Unlike previous studies that focused on mass appraisal models using AI technology, this study explores the potential of AI technology in the appraisal industry. By analyzing the perceptions of the uses and risks related to using AI technology in the appraisal industry, this study could present meaningful implications for both industry and academia.

Despite the meaningful findings of this study, it has the following limitations. First, this study investigates the perception of appraisers in the transitional state of introducing AI technology in the appraisal industry. There is a limitation in that the perception of respondents can change based on technology development or other situations. Second, this study is limited because it does not suggest a causal relationship between AI utilization and the risks of using AI technology in the appraisal industry.

\section{References}

[1] Wirth, N. (2018) "Hello Marketing, what can artificial intelligence help you with?." International Journal of Market Research 60(5), 435-438.

[2] Băjenescu, T. I. (2018) “The Risks of Artificial Intelligence." Journal of Engineering Science 25(4), 47 56.

[3] Cheatham, B., Javanmardian, K., \& Samandarim, H. (2019) McKinsey Quarterly.

Information on https://assets.noviams.com/novi-fileuploads/MISBO/Shared_Resources/AI_Resources/Confronting-the-risks-of-artificial-intelligencevF.pdf

[4] Microsoft, Microsoft AI principles Information on https://www.microsoft.com/en-us/ai/our-approach-to-ai

[5] Google, Artificial Intelligence at Google : Our Principles Information on https://ai.google/principles/

[6] Association for Computing Machinery US Public Policy Council (USACM). (2017). Statement on Algorithmic Transparency and Accountability. Information on http://www.acm.org/binaries/content/assets/publicpolicy/2017 usacm statement algorithms.pdf

[7] Bazan-Krzywoszanska, A. \& Bereta, M. (2018) "The use of urban indicators in forecasting a real estate value with the use of deep neural network." Reports on Geodesy and Geoinformatics 106, 25-34.

[8] Rossini, P. A., Kershaw, P. J. \& Kooymans, R. R. (1992) Micro-Computer Based Real Estate Decision Making and Information Management - An Integrated Approach. 2nd Australasian Real Estate Educators Conference, Adelaide. Information on http://www.prres.net/Papers/Kershaw MICROCOMPUTER BASED REAL ESTATE DECISION MAKIN G.pdf

[9] Detweiler, J. \& Radigan R. (1996) “Computer-Assisted Real Estate Appraisal: A Tool for the Practicing Appraiser." The Appraisal Journal 64(1), 91-101.

[10] Selim, H. (2009) "Determinants of House Prices in Turkey: Hedonic Regression versus Artificial Neural Network." Expert Systems with Applications 36(2), 2843-2852.

[11] Worzala, E., Lenk, M. \& Silva, A. (1995) "An Exploration of Neural Networks and Its Application to Real Estate Valuation.” The Journal of Real Estate Research 10(2), 185-202.

[12] Guan, J., Zurada, J. \& Levitan, A. S. (2008) "An Adaptive Neuro-Fuzzy Inference System Based Approach to Real Estate Property Assessment." Journal of Real Estate Research 30(4), 395-421.

[13] Rossini, P. (1997) "Artificial Neural Networks Versus Multiple Regression in the Valuation of Residential Property." Australian Land Economics Review 3(1), 1-12.

[14] Peterson, S. \& Flanagan, A. B. (2009) "Neural Network Hedonic Pricing Models in Mass Real Estate Appraisal." Journal of Real Estate Research 31(2), 147-164.

[15] Zurade, J., Levitan, A. S. \& Guan, J. (2011) “A Comparison of Regression and Artificial Intelligence Methods in a Mass Appraisal Context." Journal of Real Estate Research 33(3), 349-387. 